\title{
O ofício de contar histórias: \\ a organização da coletânea Contos Fluminenses por Machado de Assis
}

\author{
The Art of Storytelling: \\ the Arrangement of the Collection Contos Flumineses by Machado de Assis
}

Daniela Magalhães da SILVEIRA*

Resumo: Contos Fluminenses foi a primeira coletânea de contos organizada por Machado de Assis. Com uma única exceção, foi composta por narrativas que tiveram versões anteriores, publicadas no Jornal das Famílias. Contar histórias e organizá-las em livros constituía-se em um caminho viável de discussão das principais questões para a formação da literatura nacional, como também uma importante fonte de renda. O objetivo deste artigo é mostrar a importância do suporte inicial de publicação daqueles contos, bem como buscar indícios a respeito das motivações de seu autor para a realização do trabalho de organizar livros.

Palavras-chave: Machado de Assis. Contos Fluminenses. Jornal das Famílias. Leituras para moças.

Abstract: Contos fluminenses was the first collection of short stories compiled by Machado de Assis, which, with one exception, consisted of stories that had earlier been published in the Jornal das Famílias. Telling stories and arranging them in books was not only a viable way to discuss key issues in the evolution of national literature, but also an important source of income. The aim of this paper is to show the importance of the initial publishing support for those stories, and to seek clues about the motives of its author in assuming the work of compiling collections.

Keywords: Machado de Assis. Contos Fluminenses. Jornal das Famílias. Readings for girls.

\footnotetext{
* Professora doutora - Instituto de História - Universidade Federal de Uberlândia - Campus Santa Mônica. Av. João Naves de Ávila, 2121, Bloco H - sala 1H49. Cep. 38.400-902. Uberlândia - MG. danielasilveira@hotmail.com .
} 


\section{O Jornal das Famílias e os Contos Fluminenses}

O Jornal das Famílias - publicação ilustrada, recreativa, artística, etc. - fez parte dos empreendimentos editoriais de B. L. Garnier. Foi publicado entre janeiro de 1863 e dezembro de 1878, de modo que se apresentava como reformulação de outro periódico: a Revista Popular. Esta havia sido publicada pelo mesmo editor, entre 1859 e 1862. Entre os colaboradores do Jornal das Famílias, a partir de seu segundo ano de existência, começou a figurar o nome de Machado de Assis, as suas iniciais ou então alguns de seus pseudônimos ${ }^{1}$. A participação desse literato iniciouse com a publicação de "Frei Simão", totalizando em 85 contos destinados à seção "Romances e novelas” e um conto que aparecera na seção “Viagens” (SILVEIRA, 2005, p. 4). No entanto, boa parte dessas histórias não ganhou outro suporte além do próprio periódico. Enquanto colaborou para o Jornal das Famílias, Machado de Assis organizou duas coletâneas de contos. A primeira delas recebeu o título de Contos Fluminenses e foi lançada em 1870. Esse livro foi composto por 8 contos, e apenas um deles não havia sido anteriormente publicado na revista. Situação muito parecida se repetiu com a sua segunda coletânea. Nas Histórias da meia-noite, de 1872, todos os seus 6 contos haviam recebido versão anterior no Jornal das Famílias.

A revista de B. L. Garnier parece ter sido, assim, de fundamental importância para esse início de carreira de Machado de Assis. O Jornal das Famílias dividia suas páginas entre a moda francesa e a literatura nacional. Para tanto, privilegiava os interesses femininos e das famílias. Logo em seu número de abertura indicava que, na hora da escolha dos artigos que seriam publicados, prefeririam “os que mais importarem ao país, à economia doméstica, à instrução moral e recreativa, à higiene, numa palavra, ao recreio e utilidade das famílias” (A REDAÇÃO, 1863, s/p). Isso ajudou a dar o tom da participação de Machado de Assis e de outros colaboradores do periódico. Em especial pelo fato de que os textos literários precisavam considerar o público leitor feminino, seus interesses e expectativas, além de contribuírem para a construção de um perfil sólido e confiável para a revista. Por isso a manutenção de histórias com forte tom religioso e moralizante, distribuídas em seções que deveriam ajudar na formação da boa dona de casa, que saberia economizar e teria as prendas domésticas muito bem desenvolvidas.

Entre as seções regulares do periódico merecem destaque "Romances e Novelas", que recebeu a contribuição de Machado de Assis, e também “Mosaico”, “Medicina popular” e “Economia doméstica”. Estas três foram em sua grande maioria assinadas por Paulina Philadelphia. Sendo assim, “Mosaico” foi constituída por meio de “anedotas espirituosas e morais”, conforme definição encontrada na própria revista (A REDAÇÃO, 1869, p. 38). Esses escritos humorísticos 
tinham como principal função amenizar as preocupações decorrentes dos afazeres domésticos. Além disso, é preciso destacar que às leitoras eram oferecidos textos que, embora carregassem a pretensão do riso, este deveria ser pautado por determinadas regras sociais. Ao seguir esse pressuposto, sua autora procurava levar temáticas encontradas em outras seções para a composição de suas anedotas. Uma questão tratada sob a pena da galhofa foi a esperança dos escravos de alcançar liberdade. Assim apareceu:

Ninguém ignora que o motivo que leva geralmente os negros ao suicídio é a esperança que eles têm de irem ressuscitar na sua terra.

Sabendo um fazendeiro que todos os seus escravos haviam combinado enforcaremse para se livrarem dos maus tratos que lhes dava, esperando serem felizes depois da ressurreição, dirigiu-se ao lugar em que sabia ter de executar-se o plano projetado, levando também uma corda. Chegando-se a eles, disse-lhes, sem manifestar o menor abalo:

- Meus filhos, eu aprovo a vossa ideia, e venho enforcar-me juntamente convosco; porque como ireis ressuscitar em vossa terra, onde comprei uma grande porção de terreno em que trabalham de há muito os vossos companheiros que se enforcaram antes de vós, lá nos reuniremos, e assim será maior a soma de escravos que terei.

Vendo a disposição em que estava seu senhor de segui-los até depois de mortos, desistiram do intento, morreram na escravidão, com grande aprazimento do fazendeiro. (PAULINA PHILADELPHIA, 1869, p. 156).

Se alguém achou graça dessa “piadinha”, não há como afirmar. No entanto, essas palavras servem para refletirmos acerca do posicionamento político dos colaboradores do Jornal das Famílias. É indício de que havia espaço tanto para aqueles que confiavam no poder da leitura como uma prática transformadora e usavam isso para contestar algumas situações vividas por escravos, dependentes e, de modo mais amplo, pelas mulheres; mas também como um modo de reprodução de seus preconceitos. Mesmo recorrendo a posicionamentos mais conservadores, Paulina Philadelphia auxiliou na construção de um espaço cada vez mais aberto ao debate de diferentes e importantes temas para a definição dos rumos que tomariam o país. Em conjunto com as anedotas, essa articulista ainda disponibilizou ensinamentos em torno dos afazeres domésticos, bem como a melhor forma de servir cada prato, como reaproveitar os alimentos e ainda ofereceu algumas fórmulas de medicamentos que serviriam para deixar a pele e os cabelos mais sedosos, por exemplo. Constituiu-se, portanto, num dos nomes mais frequentes daquelas páginas.

Outro nome feminino que também apareceu com bastante regularidade foi o de Victoria Colonna. Enquanto Paulina Philadelphia dedicou-se mais à vida prática de suas leitoras, por assim dizer, a participação de Victoria Colonna foi direcionada no sentido de oferecer dicas de comportamento, nas quais prevaleciam um forte tom conservador e moralizante. Nesse sentido, escreveu os “Conselhos”, que levavam o seguinte subtítulo: “linhas que as criadas não devem ler” 
(VICTORIA COLONNA, 1874, p. 343). Essa frase é bastante significativa. Em primeiro lugar, pode-se aventar a respeito do fato de “criadas” serem potenciais leitoras do Jornal das Famílias. Além disso, aquela negativa pode ter provocado efeito contrário: se o texto não era recomendado, por isso mesmo deve ter despertado ainda mais a curiosidade daquelas prováveis leitoras. A autora do artigo começava afirmando que seus “conselhos” serviriam para as donas de casas que precisariam aprender a lidar com os criados que substituiriam o trabalho das escravas. Não bastava apenas ser pontual no que dizia respeito aos pagamentos dos ordenados, mas também tratá-los com a mínima polidez possível. Ou seja: “para sermos bem servidos em nossas casas, é mister que as governemos pelo regime parlamentar e não como déspotas absolutas, não admitindo sequer aos criados (como tenho presenciado) o direito de justificar-se” (VICTORIA COLONNA, 1874, p. 345). Por meio dessas palavras, Victoria Colonna considerava que suas leitoras possuíam algum conhecimento político, dominando aquela linguagem e conceitos, e que pudessem levar tal habilidade para o governo da casa.

Seguindo ainda a estratégia de elaborar seus textos com a intenção de aconselhar suas leitoras, Victoria Colonna adentrou num dos principais temas debatidos por aquelas páginas: o casamento. Para tanto, dava a entender que os casamentos mal sucedidos eram causados, em especial, devido às diferenças etárias entre os cônjuges. Enquanto as meninas se casavam muito jovens, os homens uniam-se em matrimônio, quando atingiam uma idade muito avançada. Isso acabava prejudicando até mesmo a formação física dos filhos do casal. Para terminar, sugeria, também, que as meninas deveriam ser criadas "mais amigas do trabalho e da virtude que do luxo", conselho que servia também para a orientação dos rapazes (VICTORIA COLONNA, 1875, p. 182). Como foi possível observar, Paulina Philadelphia e Victoria Colonna constituíram-se em dois nomes de fundamental importância para a composição do Jornal das Famílias, sendo as assinaturas mais regulares ao lado daquelas usadas por Machado de Assis. O que ainda ficou sem resposta diz respeito à identificação dessas duas figuras. Seriam dois pseudônimos? Paulina Philadelphia e Victoria Colonna eram mulheres ou dois redatores do sexo masculino que se aproveitaram da possibilidade de recorrer a essas assinaturas para, assim, aproximarem-se mais de suas leitoras? Possivelmente a colaboradora Victoria Colonna foi criada, tendo em vista a poetisa romana de mesmo nome, que viveu entre os séculos XV e XVI. É provável que Paulina Philadelphia também escondesse algum outro nome. Essas são questões que ainda continuam em aberto, mas que não podem servir como justificativa para diminuir a importância dessas "senhoras” para a composição do periódico. 
Ao lado de Machado de Assis e dessas “duas colaboradoras”, outros nomes apareceram com certa regularidade ${ }^{2}$. Alguns deles não recorreram ao artifício do pseudônimo, como fez Joaquim Manuel de Macedo, o padre Francisco Bernardino de Souza e Augusto Emílio Zaluar. Outros não se sabe se usaram pseudônimos ou se faziam parte dos inúmeros anônimos que tentaram ingressar no mundo das letras. A revista, aliás, incentivava essa colaboração. Em especial se os artigos contemplassem o perfil desde o início traçado para aquele periódico. Precisavam ser “artigos instrutivos e que tratem de economia doméstica, higiene e interesses do Brasil” (A REDAÇÃO, 1870, s/p). Durante os dezesseis anos em que foi publicada, essa revista conservou o mesmo formato e manteve Machado de Assis como o seu principal colaborador. Em alguns números, parecia que aquele periódico não possuía outro colaborador, contrariando a propaganda feita em fevereiro de 1869, que afirmava:

Vencidas as dificuldades, inseparáveis às primeiras tentativas, podemos com segurança e afoiteza dizer que o Jornal das Famílias vai datar do seu sétimo ano um verdadeiro e progressivo melhoramento.

Novos e ativos colaboradores assegurarão-nos a publicação de interessantíssimos romances, narrativas de viagens, biografias de senhoras ilustres, episódios de história geral e particular, descrições de cidades, vilas, etc., que tiverem maior importância, artigos sobre a educação de ambos os sexos, etc., etc. (A REDAÇÃO, 1869, p. 38).

Essas promessas mal saíram do papel. Quem cada vez mais assumiu a responsabilidade pelo preenchimento daquelas páginas foi mesmo Machado de Assis. A variedade ficava por conta das assinaturas utilizadas, causando a sensação de que diferentes autores integravam aquele corpo de colaboradores (SILVEIRA, 2005, p. 150). Desse modo, com a passagem dos anos, esse literato se tornou o principal nome do Jornal das Famílias. Por outro lado, não se pode perder de vista que, quando o seu primeiro conto apareceu naquelas páginas, o periódico já contava mais de um ano de circulação. É necessário considerar, portanto, a existência de um perfil da revista e de seu público leitor que deve tê-lo orientado ainda no começo de seu trabalho. Além mesmo da existência de “colaboradoras”, como Paulina Philadelphia e Victoria Colonna, que deveriam agradar bastante ao público, se considerar-se a manutenção dessas participações em tantos números da revista. Nesse sentido, naquele mês de junho de 1864, a revista iniciava-se com a continuação da história intitulada “O áspide na flor”, assinada por Stello. Em seguida, havia a estreia de Machado de Assis, que assinava apenas com suas iniciais: M. A. O conto em questão tem em seu centro as artimanhas utilizadas por uma família senhorial, na tentativa de impedir a realização do casamento de seu filho com uma agregada da casa. Havia a inserção de uma das questões que mais interessava tanto às prováveis leitoras do periódico, como aos próprios colaboradores: o casamento, ou seja, a escolha 
dos noivos, a geração de filhos saudáveis e o comportamento dos nubentes, com destaque para as mulheres ${ }^{3}$.

Considerando a existência de uma temática que perpassava boa parte das histórias, publicadas no Jornal das Famílias, e que, um de seus principais colaboradores já encontrou esse perfil definido, não se pode deixar de vislumbrar os artifícios e estratégias criados pelo próprio Machado de Assis, com a intenção de provocar os seus colegas de redação, atiçar os vigilantes das leituras direcionadas às mocinhas do mercado casamenteiro, bem como seguir os seus princípios como escritor de literatura. Torna-se interessante, então, observar como as histórias escolhidas para compor a sua primeira coletânea de contos transferiram para o interior do livro as discussões em torno da temática matrimonial, como também as principais polêmicas de sua escrita original e o questionamento a respeito de algumas questões que apareciam nas próprias páginas do periódico.

Nos próximos itens deste artigo, será abordada a composição da coletânea Contos Fluminenses. A intenção principal será a de oferecer uma descrição detalhada do trabalho realizado por Machado de Assis para organizar um livro com coerência e que pudesse servir como meio de discussão de uma temática que tanto interessava àquela época. Além disso, ainda buscar-se-á indícios a respeito desse início de produção literária do autor, no sentido de demonstrar a importância do Jornal das Famílias para a sua formação e para a construção da literatura brasileira. Esta abordagem começará, portanto, com o conto de abertura da coletânea, o único que não teve uma primeira versão publicada no Jornal das Famílias e nem em qualquer outro periódico.

\section{“Miss Dollar”}

Das coletâneas de contos organizadas por Machado de Assis, Contos Fluminenses foi a única que não teve suas histórias precedidas por uma “Advertência” ou um "Prefácio”. Sua abertura foi marcada pela escrita em primeira mão do conto “Miss Dollar”. O enredo dessa narrativa antecipava algumas questões trabalhadas nos outros contos da coletânea. Sendo assim, a personagem feminina central foi caracterizada como uma viúva, situação bastante utilizada por Machado de Assis em contos escritos àquela época, e ainda havia a discussão em torno do casamento por conveniência. No entanto, antes de apresentar os seus personagens principais, o narrador do conto fazia uma reflexão sobre a sua própria escrita e imaginava as reações de seus prováveis leitores, diante do enigma Miss Dollar. Um jovem e romântico leitor imaginaria que Miss Dollar seria uma "inglesa pálida e delgada, escassa de carnes e de sangue, abrindo à flor do rosto dois grandes olhos azuis e sacudindo ao vento umas longas tranças negras” (ASSIS, 1986, p. 27, v. 
2). Essa definição seguia à risca o ideal de heroína cara ao Romantismo e indicava uma possibilidade de encaminhamento da narrativa, se o autor assim tivesse caracterizado a sua personagem. Outro leitor poderia também imaginar que Miss Dollar seria “uma robusta americana, vertendo sangue pelas faces, formas arredondadas, olhos vivos e ardentes, mulher feita, refeita e perfeita” (ASSIS, 1986, p. 27, v. 2). Para completar essa descrição, seria também “fecunda e ignorante”. Assim, apresentava-se o estilo literário oposto ao Romantismo, mas que também fora rejeitado pelo autor da história. Ainda havia o leitor que já não primava pela juventude e que sugeriria que Miss Dollar fosse "uma boa inglesa de cinquenta anos, dotada com algumas mil libras esterlinas, e que, aportando ao Brasil em procura de assunto para escrever um romance, realizasse um romance verdadeiro, casando com o leitor aludido” (ASSIS, 1986, p. 27, v. 2). Por fim, o último provável leitor ainda poderia aventar que aquela que oferecia seu nome ao título da história seria simplesmente uma brasileira afortunada. Com essa incursão pelo mundo dos possíveis leitores e de suas expectativas, havia a sugestão de que a escolha do perfil daquela personagem definiria a própria filiação literária de seu autor, que optou por fazer de sua Miss Dollar uma “cadelinha galga”, abrindo mão de qualquer uma daquelas possibilidades.

Embora a cadelinha oferecesse título à narrativa, esta se desenvolveu em torno de sua dona e de Mendonça. Ou seja, uma viuvinha que parecia ser muito mais jovem do que de fato era e um candidato a segundas núpcias da moça. Em seu primeiro casamento, Margarida não havia sido feliz, porque seu esposo estava apenas interessado em gastar o dinheiro dela. Mendonça, por sua vez, conhecera Margarida, depois de ter encontrado Miss Dollar, e acabou apaixonando-se pela viúva. Aliás, enquanto Mendonça colecionava cães, Margarida havia perdido a sua cadelinha e colocado um anúncio no jornal, oferecendo uma recompensa a quem a encontrasse. Mesmo tendo gostado do animalzinho desde que o recolhera, o rapaz decidiu devolvê-lo. Nisso não fora movido pela recompensa, mas porque acreditava que seu dono ou dona estaria sofrendo aquela perda. Ao chegar à casa indicada pelo anúncio, foi recebido por uma velha senhora, que logo descobriu ser a tia de Margarida. Estavam assim configurados os personagens e o cenário onde se desenvolveriam os próximos atos. Um jovem rapaz que tinha a medicina como profissão e uma viuvinha que já havia recusado outros cinco pretendentes. Logo em suas primeiras histórias, Machado de Assis demonstra um interesse mais contundente na construção de personagens femininas viúvas, conforme ainda será visto com relação aos outros contos escolhidos para essa mesma coletânea. Essa preferência pode ser justificada por causa da maior liberdade que possuía essas mulheres. Afinal de contas, já não estavam debaixo da proteção dos pais nem de um marido, que muitas vezes comportava-se como seu senhor. Por sua vez, essas mulheres acabavam formando outras redes de solidariedade, quando buscavam parentes e agregados para compartilharem o mesmo lar. 
A narrativa teria transcorrido tranquilamente e alcançaria um final feliz, se não fosse pela fama alcançada por Margarida de recusar todos os seus candidatos a esposo e a consequente rejeição ao amor de Mendonça. Vale à pena ressaltar que, embora as viúvas possuíssem uma maior liberdade de escolha com relação ao futuro casamento, ainda assim não poderiam adiá-lo de modo indefinido. Caso contrário, passariam a ser alvo de fofocas ou receberiam a definição de "esquisita”, conforme acontecera com a própria Margarida. Esta personagem, num primeiro momento, parece não se importar com aquilo que diziam a seu respeito. Num segundo momento, no entanto, usa o argumento de que não poderia "ficar debaixo da ação da maledicência” para firmar seu casamento com Mendonça. A situação chegou a esse ponto, depois que o rapaz invadiu o quarto da moça. É interessante observar como esse fato poderia não chegar ao conhecimento de qualquer pessoa, mas Margarida, ao contrário, parece ter usado essa “desculpa” para se render aos encantos de seu conquistador impertinente. Logo ocorre o matrimônio, e Mendonça acaba deixando sua esposa sozinha na primeira noite do casal, revelando que seriam apenas amigos e que o desejo dele relacionava-se ao de salvar a reputação da viúva. Sua motivação para tal atitude vinculava-se à necessidade de mostrar à Margarida que não possuía qualquer interesse em sua fortuna. Passado algum tempo, ambos convencidos dos seus sentimentos, acabaram por transformar em "efetivo casamento apenas celebrado”.

A primeira coletânea de contos de Machado de Assis iniciava-se dessa maneira, anunciando o possível tom que poderia ser encontrado nas outras histórias. Como escritor ainda pouco conhecido pelo grande público, Machado precisava recorrer a artifícios que garantiriam algum sucesso para o novo livro. Talvez por isso a inclusão de histórias que devem ter agradado ao seu público do Jornal das Famílias, aquelas mais buriladas e também as que podem ter despertado maior curiosidade e polêmicas. Os outros seis contos constantes do livro apresentaram situações em torno de personagens que passavam por dramas muito próximos àquele vivido por Margarida, de “Miss Dollar”. Ou seja, como conciliar o matrimônio com a situação financeira mais vantajosa de uma das partes? As respostas para essa indagação foram apresentadas de modo a discutir tanto a formação da literatura brasileira, como as estratégias inventadas por personagens femininas para driblar seus senhores e a sanha de aproveitadores de mocinhas desprotegidas. 


\section{Luís Soares, Vasconcelos, Gomes...}

O segundo conto que aparece nos Contos Fluminenses leva como título o nome de um personagem masculino - "Luís Soares”. Essa narrativa, quando apareceu no Jornal das Famílias, no mês de janeiro de 1869, havia recebido as iniciais J.J. como assinatura. Os títulos oferecidos a boa parte de suas antecessoras fizeram referência às personagens femininas ${ }^{4}$, e essa outra opção parece desviar, ao menos em parte, a atenção do principal problema ali discutido. Em especial porque quem acabou atraindo mais atenção e a possibilidade de definir os rumos da história e de sua própria vida foi Adelaide. Vejamos, portanto, o porquê desse destaque e a presença paulatina de personagens com o mesmo perfil em outras histórias da coletânea.

"Luís Soares” tem início com o narrador apresentando o personagem que oferecia nome ao conto. Ou seja, alguém que trocava o dia pela noite, invertendo os horários das principais refeições, leitor de alguns romances, sem aderir à prática da leitura dos jornais, pois acreditava que eram “a cousa mais inútil desse mundo, depois da Câmara dos deputados, das obras dos poetas e das missas”. Em resumo, Luís Soares era uma "grande inutilidade”. Poderia levar essa vida, por causa da fortuna que recebera depois do falecimento de seu pai. Foram muitos contos de réis recebidos e dissipados sem qualquer reflexão de que poderiam terminar algum dia. Foi justamente isso o que aconteceu: quando menos esperava, Luís Soares estava pobre. Ou melhor, possuindo apenas seis contos de réis, o que equivalia a uma miséria para os seus padrões. A solução ideal para esse problema consistia em se tornar herdeiro de outra fortuna. Para isso, contava com um tio.

O Major Luís da Cunha Vilela, velho e doente, possuía a moral rígida. Para conquistar esse parente, Luís Soares precisaria esforçar-se bastante. Começou declarando ser um pecador arrependido e disposto a aceitar um cargo público. O trabalho aparecia como sinônimo de sofrimento e autoflagelação, em especial para alguém que nunca havia se preocupado em ganhar dinheiro dessa forma. Diante dessas declarações, o major o recebeu como um filho pródigo, oferecendo-o o melhor lugar à mesa. Logo ocorreria o primeiro encontro entre o rapaz e uma prima que vivia na mesma casa e debaixo da proteção do tio em comum. Adelaide foi obrigada a conviver com o primo, mesmo carregando uma forte mágoa. A mocinha amava-o, mas havia sido rejeitada por não possuir uma fortuna comparável a de Luís Soares. Assim que o major soube daquela afeição passada e aos poucos revigorada com a suposta mudança ocorrida no modo de vida do rapaz, tratou de interceder e sugerir que os parentes se casassem. Luís Soares bem que tentou escapar, mas a argumentação poética usada pelo personagem não estava de acordo com os fins práticos e senhoriais do major. 
Nessa história, no entanto, ainda apareceria outro senhor, enviado do além, com o objetivo de interferir no encaminhamento das vidas de Luís Soares e de Adelaide. Isso aconteceu por intermédio de Anselmo, um fazendeiro rico e galhofeiro, que havia acompanhado os suspiros derradeiros do pai da mocinha daquela história. A missão dele era a de anunciar as últimas vontades de Bento, que havia escrito uma carta, deixando uma grande fortuna para Adelaide, com a condição de que a mesma se casasse com Luís Soares. Caso a menina resistisse ao cumprimento dessa exigência, todo o dinheiro deveria permanecer com Anselmo. Aquela nova situação parecia, de fato, ter sido enviada dos céus para Luís Soares, que recebeu a notícia com os olhos cheios de “contentamento e ternura”. Segundo acreditava esse personagem, bastava seguir um plano simples: “ser diplomata” e conquistar o coração da pequena aos poucos. Não acreditava que esse fim fosse complicado, afinal de contas conhecia os sentimentos de Adelaide. Esta, porém, resistiu: respondia às perguntas do rapaz com frieza, devolvia as cartas enviadas por ele e, finalmente, zombou de uma declaração de amor feita de joelhos, afirmando que trezentos contos era "muito dinheiro para comprar um miserável”. Depois dessa cena, Adelaide procurou aqueles senhores que pareciam deter o poder de decisão sobre o futuro dela e contou o que havia ocorrido. Ao contrário daquilo que Adelaide acreditava, Anselmo não seguiu as ordens do amigo, entregou o dinheiro para ela e toda a família partiu para a Europa, com exceção de Luís Soares que acabou se suicidando, tomando assim a “resolução dos cobardes”, conforme definia o narrador do conto.

Para além das desventuras de um rapaz que abominava o trabalho e que gostaria de viver de heranças deixadas por parentes, essa é uma narrativa que descreve o lugar ocupado por uma mulher dependente da boa vontade senhorial. Adelaide é a agregada pobre que sobrevive graças ao amparo oferecido pelo senhor Vilela, que só morreria tranquilo caso unisse, por meio do matrimônio, os seus dois sobrinhos. Empenhado nesse mesmo objetivo, outro senhor surge do mundo dos mortos, por meio de uma carta-testamento ${ }^{5}$. Ao contrário de Luís Soares que tenta enganar seus tios/senhores, fingindo aceitar as imposições deles, Adelaide contraria todas as expectativas lançadas sobre suas decisões. Existe por detrás dessa personagem uma tentativa de negar o domínio senhorial. Com esse epílogo inesperado, Luís Soares passa a ser sinônimo de covardia, enquanto Adelaide poderia ser vista como o exemplo de superação e boa índole e que, por isso, fora recompensada. Aliás, essa era a principal justificativa para a escrita daquelas histórias. Ou seja, levar para as mocinhas leitoras do Jornal das Famílias lições, exemplos de comportamento que pudessem ser usados no dia a dia ou “conselhos” conforme definição de Victoria Colonna. Isso acabou sendo transferido para o cerne da coletânea Contos Fluminenses. 
Outro personagem construído com o mesmo material de Luís Soares apareceu em "O segredo de Augusta”. Assim foi caracterizado Vasconcelos:

[...] era um homem de quarenta anos, bem apessoado, dotado de um maravilhoso par de suíças grisalhas, que lhe davam um ar de diplomata, cousa de que estava afastado umas boas cem léguas. Tinha a cara risonha e expansiva; todo ele respirava uma robusta saúde.

Possuía uma boa fortuna e não trabalhava, isto é, trabalhava muito na destruição da referida fortuna, obra em que sua mulher colaborava conscienciosamente. (ASSIS, 1986, p. 82, v. 2).

Esse personagem, conforme pode ser observado, assemelhava-se em muitos pontos com aquele que havia aparecido no conto analisado anteriormente. Para completar, Vasconcelos ainda contava com a companhia de mais dois amigos: Batista e Gomes. Este último, em seu relato autobiográfico, confessava que havia sido até aquele momento "um verdadeiro estróina, um perfeito pândego, gastando às mãos largas” a sua fortuna. Como poderia se esperar, essa vida desregrada havia levado tanto Vasconcelos quanto Gomes à mesma situação de miséria, enfrentada por Luís Soares, e também à solução idêntica - o casamento. Vasconcelos pretendia casar a sua única filha para assim manter aquele estilo de vida. Gomes, por sua vez, resolveu declarar-se apaixonado justamente pela filha de Vasconcelos, acreditando que o amigo ainda seria portador de uma fortuna considerável. Estava assim armada toda uma trama em torno da vida futura da filha de Vasconcelos. Nenhum desses personagens masculinos, no entanto, considerava os desejos da menina, apenas a necessidade de refazer suas fortunas sem precisar trabalhar para isso.

Em “O segredo de Augusta”, aparece mais uma personagem que recebeu o nome de Adelaide $^{6}$. Esta, agora, era a filha do casal Vasconcelos. Havia sido criada na roça e não compreendia muito bem os hábitos de seus pais. Para transformá-la, contava com os ensinamentos da mãe, que tentava inserir a filha em seu círculo de convivência. Uma e outra se pareciam muito. Ambas eram belas, jovens e poderiam ser confundidas como irmãs e não reconhecidas como mãe e filha. Ainda mais porque Augusta fazia questão de confundir os anos. Aliás, Augusta parecia esposa perfeita para Vasconcelos, não fazendo cobranças ao marido e ajudando-o a gastar o dinheiro do casal com vestidos caros. A harmonia dessa família começou a desafinar, quando chegou a notícia da falência. Com o intuito de tentar resolver aquela situação da maneira mais conveniente, Vasconcelos começou consultando a própria filha. Adelaide, no entanto, foi enfática: não estava disposta a se casar porque não gostava de ninguém. Para dobrá-la, Vasconcelos recorreu a argumento corrente entre as próprias mulheres ${ }^{7}$. Alertava a menina de que o casamento poderia livrá-la de uma situação mais complicada, caso perdesse os pais. Além disso, mostrava que já havia até escolhido o noivo ideal: “um bonito rapaz, de bom coração [...]” (ASSIS, 1986, p. 89, v. 2). 
Mas, como nada parecia suficiente para convencê-la, Vasconcelos acabou recorrendo à imposição e lembrando-a de que “o primeiro dever de uma filha é obedecer a seu pai” (ASSIS, 1986, p. 90, v. 2). Adelaide encontrava-se, assim, num beco sem saída.

Não demorou muito para que essa situação chegasse aos ouvidos de Augusta. Para surpresa de Vasconcelos, sua esposa mostrou-se contrária ao casamento e não cedeu nem mesmo depois de saber que aquela poderia ser a solução mais rápida e fácil para que não caíssem na pobreza. Augusta não levava uma vida de dona de casa, conforme se esperava das mulheres suas contemporâneas, segundo aquilo que ficava explícito nas próprias páginas do Jornal das Famílias, nas colunas assinadas por Paulina Philadelphia e Victoria Colonnna, por exemplo. Já se sabe que Adelaide não fora criada pela mãe, quando médicos dedicados à saúde das crianças afirmavam sobre os perigos de se enviar os filhos para que outras pessoas cuidassem deles ${ }^{8}$. Havia sido parceira nas gastanças de seu esposo, preocupando-se apenas em adornar a sua vaidade, um dos principais pecados apontados por moralistas e religiosos atentos à boa condução da vida doméstica ${ }^{9}$. Nesse sentido, torna-se interessante acompanhar a discussão entre marido e mulher:

- Mas por que motivo não impediu o senhor essas despesas que eu fazia?

- Queria a paz doméstica.

- Não! Clamou ela; o senhor queria ter por sua parte uma vida livre e independente; vendo que eu me entregava a essas despesas imaginou comprar a minha tolerância com a sua tolerância. Eis o único motivo; a sua vida não será igual à minha; mas é pior... Se eu fazia despesas em casa o senhor as fazia na rua... É inútil negar, porque eu sei tudo; conheço, de nome, as rivais que sucessivamente o senhor me deu, e nunca lhe disse uma única palavra, nem agora lho censuro, porque seria inútil e tarde. (ASSIS, 1986, p. 94, v. 2).

Observa-se, aqui, a confirmação de que aquele casal estava muito longe de constituir-se em exemplo para qualquer leitor ou leitora. Além disso, Adelaide parecia mesmo encontrar-se numa situação bastante complicada, que iria se desenrolar apenas por causa da insistência de sua mãe em não permitir o casamento dela. Conforme se vem acompanhando, Augusta estava muito mais preocupada em seu bem-estar e em manter a aparência de uma mulher bela e jovem do que em saber os reais sentimentos e necessidades de sua filha. Sendo assim, a justificativa para a sua rejeição àquele casamento girava em torno do fato de que os filhos da menina seriam, consequentemente, netos dela, denunciando a idade da mulher vaidosa ${ }^{10}$. Uma leitura possível desse conto serviria como forma de chamar a atenção das mulheres que se espelhavam no comportamento de Augusta e também dos homens que gastavam todo o dinheiro em bailes e outras frivolidades. Por outro lado, além da iminente miséria, não existe qualquer outra lição mais pesada aos personagens. Claro que, para quem vivia conforme Vasconcelos e Gomes, essa situação era bastante complicada. 
Ainda assim, o conto encerra-se com os dois homens seguindo os mesmos hábitos e Gomes dando continuidade aos seus planos de arranjar uma esposa rica que pudesse bancar sua boa vida. Sem falar que Augusta não se tornou avó, podendo continuar mentindo a respeito de sua idade.

“Luís Soares” e “O segredo de Augusta” foram escritos para corresponder aos interesses do público leitor do Jornal das Famílias. Para isso, no entanto, Machado de Assis deixou-os abertos para uma leitura um pouco menos repressora, de modo que as "lições” e os "bons exemplos” nem sempre apareciam de forma explícita. Foram esses contos com mais possibilidades de leituras os escolhidos para compor a coletânea Contos Fluminenses. Ou seja, aqueles que não se encerravam com um castigo ou com uma repreensão motivados por supostos comportamentos inadequados.

\section{Madalena, Emília, Eugênia...}

Para que algumas mensagens deixadas por Machado de Assis nos Contos Fluminenses surtissem qualquer efeito mais significativo, esse literato precisou contar com o poder de imaginação das suas leitoras. Essa característica, considerada pelo próprio Machado como intrínseca ao gênero feminino, foi instigada, primeiro, com as possibilidades oferecidas pelo Jornal das Famílias. Se por um lado, quando escrevia para aquelas páginas precisava atender a certos prérequisitos morais e religiosos, por outro, poderia adiar essa lição para o final da história contada. Como boa parte de seus contos ali publicados foram divididos em mais de um número, poderia deixar a dúvida no ar, sobre o que aconteceria com cada personagem, por um mês inteiro. Essa vantagem da publicação seriada perdia-se na edição do livro. Ainda assim, o suporte final dessas histórias contém bastante da expectativa da parte do autor de que seu público fosse levado a imaginar situações inusitadas. Dessa forma, muitos leitores e leitoras do século XIX devem ter se perguntado o que seria capaz de confessar uma viúva moça ou qual o segredo de uma mulher casada e ainda que punição deveria ser dada a viúvas que abusavam da liberdade conquistada depois do falecimento do marido. Ao responder essas inquietações, Machado de Assis preferiu criar personagens femininas que questionaram o papel atribuído às senhoras de seu tempo. Ou seja, suas personagens negaram o lugar figurativo de quem deveria apenas complementar o casal ou então seu narrador adiou o aparecimento da punição para as últimas linhas do conto, depois de se divertir e de divertir bastante quem acompanhava tal aventura.

A primeira personagem feminina de vida duvidosa, por assim dizer, dos Contos Fluminenses apareceu em “A mulher de preto”, no qual se encontra Madalena. Essa, no entanto, só apareceu depois de feitas as apresentações de Estevão e de Meneses. O primeiro foi descrito como um "rapaz sério”, que possuía “talento, ambição e vontade de saber” (ASSIS, 1986, p. 62, v. 2). Meneses, por 
sua vez, foi configurado como um deputado de hábitos reclusos. Entre esses dois senhores estava Madalena: "uma viúva de trinta e quatro anos, bela como o dia, graciosa e terna” (ASSIS, 1986, p. 66, v. 2). Logo depois que essa mulher foi apresentada ao jovem Estevão, tudo parecia se encaminhar para o casamento. O rapaz, rapidamente, percebeu que estava apaixonado, enquanto a moça insistia em mantê-lo próximo, sem colocar em questão qualquer dúvida a respeito das intenções de tal amizade. Por outro lado, acreditar que Madalena correspondia àquele sentimento era um detalhe que dependia dos olhos do observador. Assim, enquanto o rapaz buscava coragem para se declarar apaixonado, Madalena resolveu lhe contar porque havia se aproximado dele. Na verdade, a moça não era uma viúva, mas uma mulher abandonada por causa dos ciúmes do marido. Este marido era ninguém menos do que o deputado, amigo de Estevão. Madalena insistia naquela amizade para que Estevão a ajudasse a provar sua inocência diante de Meneses. No epílogo, o casal se reconciliou com a ajuda de Estevão. Agindo dessa forma, Madalena soube aproveitar aquela aproximação e o sentimento que o rapaz nutria por ela.

Outra viúva que sabia muito bem aproveitar-se da sua condição era Emília, de "Linha reta e linha curva” (ASSIS, 1986, p. 117-152, v. 2). Essa vivia aprontando. Sabia manipular um velho senhor o qual acreditava ser namorado dela, quando, na verdade, servia apenas para acompanhá-la em seus passeios, constituindo-se em um “braceiro infalível para a rua” (ASSIS, 1986, p. 124, v. 2). Para completar, estava certa de que dobraria outro senhor que havia desdenhado do sexo feminino, afirmando preferir uma partida de voltarete ao amor de uma mulher. Toda a narrativa passa, assim, a ser desenvolvida em torno dos planos de Emília para seduzir Tito, com a finalidade de depois abandoná-lo. A intenção da moça era apenas a de vingar as mulheres que, segundo acreditava, haviam sido humilhadas pelo desdém do rapaz. Qual a punição oferecida à Emília no último capítulo dessa história? A viúva acabou apaixonando-se e explicando aquele sentimento como uma forma de castigo, porque acreditava que não seria correspondida. Mas, ao contrário, terminou feliz e ao lado do homem que amava. Punição, no mínimo, bastante doce para ambos os envolvidos.

Uma terceira viúva bastante polêmica pode ser encontrada em “Confissões de uma viúva moça” (ASSIS, 1986, p. 99-117, v. 2). Ao contrário das outras, as aventuras de Eugênia são contadas por ela mesma sob o formato de cartas a uma amiga. Esse conto já rendeu alguma discussão, desde quando foi publicado no Jornal das Famílias, até a crítica póstuma de Machado de Assis (PEREIRA, 2008). No entanto, o que interessa aqui é mostrar como o autor adiava o máximo possível a "lição" que deveria deixar, levando seus leitores e, em especial, suas leitoras a imaginar o que bem entendessem a respeito do tema abordado. Nesse sentido, é preciso acompanhar com mais vagar o desenrolar dessa trama, considerando sua publicação inicial ainda no periódico feminino. 
As confissões de Eugênia começaram a ser publicadas em abril de 1865 e foram assinadas pela letra J. A forma adotada pela narradora a livraria de qualquer constrangimento, por causa da distância imposta no momento da leitura das cartas, e ainda causaria o "efeito de um folhetim de periódico semanal” (J., 1865, p. 98). Isso significaria que a amiga de Eugênia e as leitoras do Jornal das Famílias deveriam "gostar e aprender” com tal narrativa. Além disso, completava a narradora, afirmando que “a lição há de servir-me, como a ti, como às nossas amigas inexperientes. Mostralhes estas cartas; são folhas de um roteiro que se eu tivera antes, talvez não houvesse perdido uma ilusão e dois anos de vida” (Jornal das Famílias, abril de 1865). Por meio dessas palavras, ficava clara a intenção da narradora, sendo esse preâmbulo um primeiro aviso àqueles que pudessem suspeitar da imoralidade da narrativa. Depois disso, Eugênia começava o seu relato, afirmando que, quando seu marido ainda era vivo, a casa dela funcionava como ponto de reunião, além de a Corte ter, àquela época, várias opções de divertimentos. A mulher reinava em todos os lugares onde estava e impunha suas vontades, ignorando as decisões do marido. No Teatro Lírico, conheceu um cortejador que lhe chamou mais atenção do que os outros. Ainda mais pela ousadia que teve, enviando-a uma carta na qual se declarava apaixonado por ela. Logo depois de queimar a prova de um pecado que ainda nem havia cometido, Eugênia percebeu que seu marido se aproximava. A mulher, então, procurou refúgio nos braços dele, mas não encontrou qualquer demonstração de afeto. Assim concluía aquele mês, deixando uma pergunta às leitoras: "Senti uma lágrima rolar-me pela face. Seria a primeira advertência do pecado?” (J., 1865, p. 103).

Provavelmente essa forma de encerrar o conto foi calculada com a intenção de deixar as leitoras curiosas. No entanto, o interesse em acompanhar a narrativa a respeito de uma suposta traição poderia não ser visto como o mais adequado para uma revista que possuía o perfil do Jornal das Famílias. Isso foi alertado por alguém que assinava como “O Caturra”, na seção de “A Pedidos”, do Correio Mercantil. Assim afirmava:

No último número desse jornal, que se diz das famílias, e de cujo programa já vai se afastando sofrivelmente, enceta-se a publicação de um romancito sob o título Confissões de uma viúva moça.

Pela amostra do pano desde já se pode conjecturar de que magnificência será o vestido que trata-se (sic) de expor à atenção das jovens, que têm um dia de serem esposas e mães de família, isto é, daquelas que bem deverão compreender qual a verdadeira missão da mulher, os deveres, trabalhos que exigem a criação e educação dos filhos, e os legítimos gozos ocorrentes que suavizam os frequentes cuidados da respeitável mãe de família. Para os pais de família, pés de boi, os que têm a esquisitice de verem as realidades deste mundo pelo prisma do rococó, escrevemos estas ligeiras linhas, pedindo-lhes que façam companhia às suas filhas na apreciação de tão edificantes escritos, tão harmoniosos com os esplendores deste século reformista. (O CATURRA, 1865, s/p). 
O autor do artigo chamava atenção não para a falta de qualidade literária do conto, por exemplo, mas por considerá-lo inapropriado para aquela revista. Havia chegado a essas conclusões, aliás, sem esperar por seu epílogo. Logo na primeira parte da história já ponderava o quanto a imaginação feminina poderia ganhar asas e alcançar lugares os quais não deveriam ser frequentados, segundo suas concepções, por aquelas que se tornariam, em breve, mães de família. Esse questionamento à publicação das “Confissões de uma viúva moça” não ficou sem resposta. No dia seguinte, apareceu, no Diário do Rio de Janeiro, outro artigo, acusando “O Caturra” de inimigo pessoal do editor do Jornal das Famílias, com um breve resumo da história até o ponto em que fora contada e mais um convite para que as leitoras conferissem, se havia algum comprometimento à moral naquelas linhas. Para completar, ainda naquele mesmo mês de abril, outro "pai de família” recorreu ao Correio Mercantil com a finalidade de demonstrar o seu posicionamento. Esse assinava como "Um Velho" e pedia "aos pais escrupulosos que não consintam a leitura de semelhante romance, embora as filhas os chamem de rabugentos. Abracemo-nos com os preceitos da moralidade, e condenemos essas doutrinas perigosas pelas quais daremos contas a Deus” (UM VELHO, 1865, s/p). Estava assim armada toda uma confusão que mais servia para beneficiar a leitura do próprio conto na revista.

Na abertura do número de maio do Jornal das Famílias, Eugênia continuava suas confissões. Começava afirmando que havia decorrido um mês sem que qualquer mudança viesse alterar aquele quadro. Por meio desse intróito, o literato igualava o tempo ficcional da narrativa àquele das leitoras empíricas. O conto prosseguia mostrando como havia ocorrido a entrada do conquistador Emílio, autor das cartas amorosas, na casa de Eugênia. Essa aproximação facilitava bastante o envolvimento do suposto casal e a confirmação do adultério. Pois Eugênia poderia reparar melhor as qualidades daquele homem e compará-lo com os outros. Além disso, as leitoras ainda acompanharam uma definição corrente àquela época a respeito do casamento: o de Eugênia havia sido "resultado de um cálculo e de uma conveniência” (J., 1865, p. 132), e o marido dela entendia o matrimônio "ao modo da maior parte da gente; via nele a obediência às palavras do Senhor no Gênesis” (J., 1865, p. 132). Essa compreensão era apropriada, quando estava em jogo assegurar o bem-estar financeiro das mocinhas e também para controlar aquelas que tentavam driblar certas convenções sociais. Mostrava qual o lugar preestabelecido para as mulheres dentro do casamento e aparecia em conformidade com os ditames do próprio “Caturra”. Ou seja, as leitoras do conto deveriam ver no casamento o lugar da procriação. Por sua vez, Eugênia parecia contestar essa suposta verdade. Boa parte dos capítulos III e IV do conto serviu, também, para que as leitoras observassem uma senhora casada, tentando resistir à sedução de um amigo do marido dela. Mais 
uma vez, o corte da história havia sido colocado em um lugar bastante estratégico, deixando perguntas às leitoras, assim como acontecera no mês anterior. Agora, atormentada pela possibilidade de seu possível amante ter ficado doente, Eugênia contava sua história e questionava à amiga e às leitoras da revista:

Passei uma noite angustiosa. A ideia de Emílio perturbava-me o sono. Afiguravase-me que ele estaria àquela hora chorando lágrimas de sangue no desespero do amor não aceito.

Era piedade? Era amor?

Carlota, era uma cousa e outra cousa. Que podia ser mais? Eu tinha posto o pé em uma senda fatal; uma força me atraía. Eu fraca, podendo ser forte. Não me inculpo senão a mim.

Até domingo. (J., 1865, p. 137).

Encerrando o número com esses questionamentos, Machado não apenas construía o lugar de inserção do corte da narrativa de um mês para o outro, como também oferecia material suficiente para que suas leitoras refletissem acerca da situação de Eugênia. Por meio de perguntas provocadoras, suas interlocutoras ficcionais e reais passavam a fazer parte da própria história contada. Talvez esse fosse o principal perigo visto por aqueles que o interpelavam por meio dos “ $\mathrm{A}$ pedidos” dos jornais diários, e não as atitudes da personagem. Desse modo, depois da publicação dessa segunda parte das confissões de Eugênia, os autores dos “A pedidos” foram ainda mais enfáticos. Acusaram o Jornal das Famílias de “apostolo do lourerismo” e o autor do conto de “mestre na especialidade erótica” (O CATURRA, 1865, s/p). Depois de acusações tão enfáticas, o autor, que até agora se escondia por detrás da letra J, resolveu se revelar de forma sucinta: “Sou o autor do romance que, com este título, publica atualmente o Jornal das Famílias. Peço ao Sr. Caturra que aguarde o resto do escrito para julgar da sua moralidade, - sem o que, qualquer discussão será inútil” (ASSIS, 1865, s/p). Machado de Assis acabava, assim, revelando a estratégia usada em muitos dos contos escritos para a revista em questão: adiar o máximo possível a lição ou o castigo para algumas personagens femininas.

Quando recorria a esse subterfúgio, Machado de Assis pretendia agradar aos vigilantes das leituras feitas por mocinhas no mercado casamenteiro sem deixar de oferecer espaços para aquelas leitoras mais criativas e inventivas. Assim, talvez estivesse mais de acordo com a função que ele mesmo acreditava que a imprensa tivesse. Ou seja, provocar revoluções. Por sua vez, o "Sr. Caturra” não parece ter se convencido com o pedido de paciência solicitado pelo literato. Aliás, o articulista rabugento demonstrava ter compreendido o sentido daquele tipo de escrita morosa, afirmando que não estava julgando nem o autor nem a moralidade do conto, mas a sua publicação num veículo dirigido às jovens mocinhas e ainda completava: 
Que importa que o autor afinal faça fulgurar a virtude, se esta, penosamente fez o seu trajeto pelos floridos vergéis do vício, cujos embriagantes perfumes atordoaram a suscetível imaginação da leitura em sua idade das ilusões? A virtude fulgurará de certo ante os espíritos já formados, mas naturalmente chegará pálida e desmaiada ante olhos juvenis, ofuscados pelos relâmpagos das grandes paixões, e que a encararão distraídos como insípida. O veneno então já estará inoculado, e os antídotos mal contendo a explosão do mal, a ação destruidora, não restituirão intacta ao enfermo a sua saúde perdida. (O CATURRA, 1865, s/p).

A estratégia tão apreciada pelo jovem Machadinho parecia ter sido descoberta por “ $\mathrm{O}$ Caturra”. De nada adiantava apresentar qualquer tipo de correção, se as leitoras inventivas já haviam sido estimuladas a percorrer caminhos considerados duvidosos, segundo a moral da época. Desse modo, o próprio “O Caturra” parecia confiar (ou desconfiar) no (do) poder de imaginação feminino. Machado de Assis desconsiderou mais aquela acusação e prosseguiu com a narrativa da viúva moça. No último mês de publicação, encontra-se, finalmente, o “castigo” atribuído à Eugênia. Antes disso, no entanto, seu cortejador recorreu a um último subterfúgio na tentativa de conquistar sua amada. Inventou uma doença e sugeriu que poderia morrer caso não a conquistasse. A única coisa que conseguiu foi a manutenção de uma correspondência proibida, pois a mulher não aceitou a proposta de fugir com ele. Eugênia alegava o desejo de permanecer "até certo ponto... pura". Nesse ínterim, o marido "traído" foi acometido por uma moléstia súbita e acabou falecendo em poucos dias. Seria a solução perfeita para o romance de Eugênia e Emílio. Mas, como havia afirmado J., no final do conto, apareceria o castigo para aquela mulher. Quando Eugênia pensava que viveria seu grande amor, recebeu a notícia de que Emílio partiria em viagem. Num primeiro momento, o sedutor negou o boato e afirmou não passar de uma viagem de negócios, contudo deixou uma carta à viúva, com o seguinte teor: "Menti, Eugênia; vou partir já. Menti ainda, eu não volto. Não volto porque não posso. Uma união contigo seria para mim o ideal da felicidade se eu não fosse homem de hábitos opostos ao casamento. Adeus. Desculpa-me, e reza para que eu faça boa vagem. Adeus, Emílio” (J., 1865, p. 167). Em seguida, aparecia a avaliação da própria Eugênia a respeito do ocorrido:

Avalias facilmente como fiquei depois de ler esta carta. Era um castelo que se desmoronava. Em troca do meu amor, do meu primeiro amor, recebia deste modo a ingratidão e o desprezo. Era justo: aquele amor culpado não podia ter bom fim; eu fui castigada pelas consequências mesmo do meu crime.

Mas, perguntava eu, como é que este homem, que parecia amar-me tanto, recusou aquela de cuja honestidade podia estar certo, visto que pôde opor uma resistência aos desejos de seu coração? Isto me pareceu um mistério. Hoje vejo que não era; 
Emílio era um sedutor vulgar e só se diferenciava dos outros em ter um pouco mais de habilidade que eles. (J., 1865, p. 168).

Provavelmente essa polêmica não passou de um artifício publicitário utilizado por Machado de Assis e pelo seu editor, B. L. Garnier, com o intuito de chamar a atenção das leitoras e também dos leitores caturras para o Jornal das Famílias, num momento delicado e correspondente ao da Guerra do Paraguai ${ }^{11}$. Quando as atenções do público voltavam-se para as notícias em torno da guerra, publicadas em jornais diários, nada melhor do que recorrer a essas mesmas folhas para espalhar a curiosidade a respeito do encaminhamento da escrita de um conto. Por outro lado, independente da sua veracidade, essa polêmica revela um pouco sobre as estratégias utilizadas por Machado de Assis, como colaborador daquele periódico: se as lições eram de fundamental importância, essas poderiam ser adiadas, abrindo, assim, as histórias para as mais diversas interpretações.

É preciso considerar que com a escrita das “Confissões de uma viúva moça” e de todos aqueles Contos Fluminenses, o autor questionava o encaminhamento oferecido por críticos seus contemporâneos. Ou seja, o "bom” romance seria aquele que transformasse a vida dos personagens em exemplos que deveriam ser seguidos pelos leitores e leitoras ${ }^{12}$. Esta parecia ser uma das principais recomendações de alguns de seus leitores. Machado de Assis, no entanto, nem sempre reduziu suas histórias à construção dessas lições. Algumas vezes, recorreu ao exemplo ambíguo, ao seu adiamento e, até mesmo, à sua não colocação. Nesse sentido, quando adiou a punição oferecida à Eugênia, deixando a "lição" para o final da história, ao mesmo tempo que contribuiu para a transmissão de determinados valores, atendendo às solicitações dos “caturras” e da própria revista, também permitiu interpretações surpreendentes, de acordo com a imaginação das suas leitoras inventivas. São possibilidades de leituras que fugiam do controle de pais, maridos e quaisquer outras pessoas interessadas em reduzir os espaços de atuação daquelas mulheres. Talvez o efeito disso não fosse tão contundente, depois que as narrativas ganhassem o suporte do livro. Afinal de contas, a partir daquele novo momento, a história poderia ser lida de uma só vez. A escolha daquelas que comporiam o livro, no entanto, deve ter partido do princípio de que, mesmo sob aquele novo formato, já deveriam ter conquistado uma boa parcela de leitoras, além da própria qualidade literária de cada um daqueles contos.

\section{“Quem conta um conto...”}


Quais os objetivos de Machado de Assis com a composição de um livro de contos anteriormente publicados em uma revista de moda e literatura? É provável que fosse o desejo de reunir num mesmo lugar suas histórias preferidas, aquelas que tenham despertado mais a atenção das suas leitoras, mas também deixar claro qual o seu posicionamento diante de algumas discussões literárias mais propriamente e, por que não, ganhar dinheiro. Aqueles que compuseram os Contos Fluminenses foram escolhidos entre pelo menos 30 contos escritos para o Jornal das Famílias, entre junho de 1864 e janeiro de 1870. Conforme já se acompanhou, o conto "Confissões de uma viúva moça” rendeu interessante debate nos jornais diários e isso deve ter levado o público leitor a não esquecê-lo. Desse modo, não poderia ter sido deixado de fora daquele livro. "Linha reta e linha curva” foi, talvez, uma das narrativas mais trabalhadas por Machado de Assis. Fora escrita como peça de teatro, em seguida, transformada para o formato de folhetim até receber a versão final do livro (SILVA, 2003). Essa insistência da parte do literato em reescrever a mesma história, reformulando algumas passagens e substituindo os nomes de determinados personagens, indica sua preferência por aquela narrativa, com relação às outras escritas na mesma época. Os outros quatro contos retirados do Jornal das Famílias para a formação da coletânea são representativos daquele grupo de histórias, possuindo temáticas e discussões aproximadas. Provavelmente, foram os escolhidos porque possuíam um estilo que agradava mais ao próprio literato. São contos que mostram qual a função da literatura numa revista dirigida ao público feminino. Por outro lado, se um dos princípios seguidos pelo Jornal das Famílias exigia de seus autores certas convenções morais, esses mesmos literatos aproveitaram aquele espaço para a divulgação e consolidação da literatura nacional. Mesmo com suas criações literárias restringidas pelo perfil do periódico, ainda assim existiam espaços para a invenção, tanto da parte dos escritores quanto dos leitores e das leitoras que, aos poucos, ganhavam mais liberdade de leitura.

Desde a sua primeira participação, no Jornal das Famílias, Machado de Assis parecia decidido a criar, naquelas páginas, um lugar para debater algumas questões ligadas à formação da literatura brasileira. Não deve ter sido por acaso que "Frei Simão" acabou sendo escolhido para fechar os Contos Fluminenses. Além de conter nessa narrativa uma discussão em torno das artimanhas do pai do protagonista, o literato aproveitava-se para mostrar as várias funções adquiridas por um romancista àquela época. Sendo assim, o personagem que ajudaria o pai de Simão a separar o filho dele de Helena havia sido um escritor de romances em sua juventude. Agora aquele senhor precisava que seu amigo escritor fosse "inventando circunstâncias e ocorrências imprevistas” (ASSIS, 1986, p. 155, v. 2). Simão e Helena, por sua vez, também encontraram na 
poesia uma maneira de encurtar a distância que os separava. Por meio de cartas, Simão mostrava como possuía um estilo refinado.

No entanto, foi apenas com a escrita de “A mulher de preto” e também com a publicação sob o formato de folhetim do conto "Linha reta e linha curva” que o jovem Machadinho começou a desenvolver uma estratégia que se tornaria recorrente em suas críticas a determinados gêneros e protocolos de escrita. A ideia consistia em suspender a escrita do conto e inserir excertos de peças ou romances considerados de baixa qualidade. No primeiro conto, quando o personagem Estevão estava mais preocupado em conquistar a suposta viúva Madalena, foi obrigado a ouvir algumas cenas escritas por um amigo. Machado de Assis interrompeu a narrativa, dessa forma:

- Adeus, Estevão! Disse o recém-chegado. Estavas escrevendo algum libelo ou carta de namoro?

- Nem uma nem outra cousa, respondeu Estevão secamente.

- Dou-te uma notícia.

- Que é?

- Entrei na literatura.

- Ah!

- É verdade, e venho ler-te a primeira comédia.

- Deus me livre! Disse Estevão levantando-se.

- Hás de ouvir, meu amigo; ao menos algumas cenas; dar-se-á caso que não me protejas nas letras? Anda cá; ao menos duas cenas. Sim? É pouca cousa.

Estevão sentou-se.

O dramaturgo continuou:

- Talvez prefiras ouvir a minha tragédia intitulada - O Punhal de Bruto...

- Não, não; prefiro a comédia: é menos sanguinária. Vamos lá. (ASSIS, 1986, p. 72, v. 2).

Vencida a primeira resistência imposta por Estevão, o dramaturgo começou a leitura com uma voz "pausada e fanhosa”. As duas cenas da comédia apareceram em seguida, obrigando os leitores e as leitoras de Machado de Assis a suspender por aquele momento a continuação do conto. A impaciência desse personagem e sua reação de desagrado diante da leitura serviam para alertar sobre a falta de qualidade literária de escritos daquele naipe. Essa mesma forma de escrita voltaria a ser usada em "Linha reta e linha curva”. Dessa vez, no entanto, o personagem Tito transformou-se num contador de histórias com a finalidade de afastar o impertinente Diogo da viúva Emília. Conforme pode ser observado, com base nas situações descritas tanto em um como no outro conto, aquela literatura de má qualidade poderia ser utilizada para afugentar os leitores. Aliás, essa parecia ser uma das principais inquietações de boa parte dos homens de letras contemporâneos a Machado de Assis. Ou seja, conquistar e manter a fidelidade dos leitores e das leitoras. Se forem levados em consideração os números referentes à alfabetização, obtidos por meio dos recenseamentos, pode-se perceber como esses escritores deveriam realmente se preocupar ${ }^{13}$. Por outro lado, o Jornal das 
Famílias deveria ter um público fiel e capaz de manter as despesas mínimas, caso contrário não teria sido publicado por tantos anos seguidos.

Sendo assim, pode-se aventar que conquistar leitores para uma revista de moda e literatura deveria ser uma tarefa bem menos complicada do que vender livros de contos, por exemplo. Por outro lado, ter um livro publicado era uma situação almejada por muitos daqueles que integravam o circuito literário. Por causa do reconhecimento entre os próprios pares e também devido ao retorno financeiro. Para alcançar essa distinção, esses literatos precisavam, além de leitores, de alguém que se responsabilizasse pela edição. Nesse sentido, Contos Fluminenses teve como editor B. L. Garnier que também cuidava do Jornal das Famílias. Para a sua publicação, Machado de Assis recebeu a quantia de 200 réis por cada exemplar, de uma obra que obteve a tiragem de mil livros (PINHEIRO, 2007, p. 278). Para um jovem autor que ainda trilhava os primeiros passos no mundo das letras, esse valor deveria ser bastante significativo. Em especial, quando se considera as dificuldades encontradas por vários literatos para publicar suas obras. Isso não passou despercebido pela imprensa da qual Machado fazia parte. Assim, o número de 20 de fevereiro de 1870, da Semana Illustrada, ganhou uma capa com a seguinte caricatura (Figura 1):

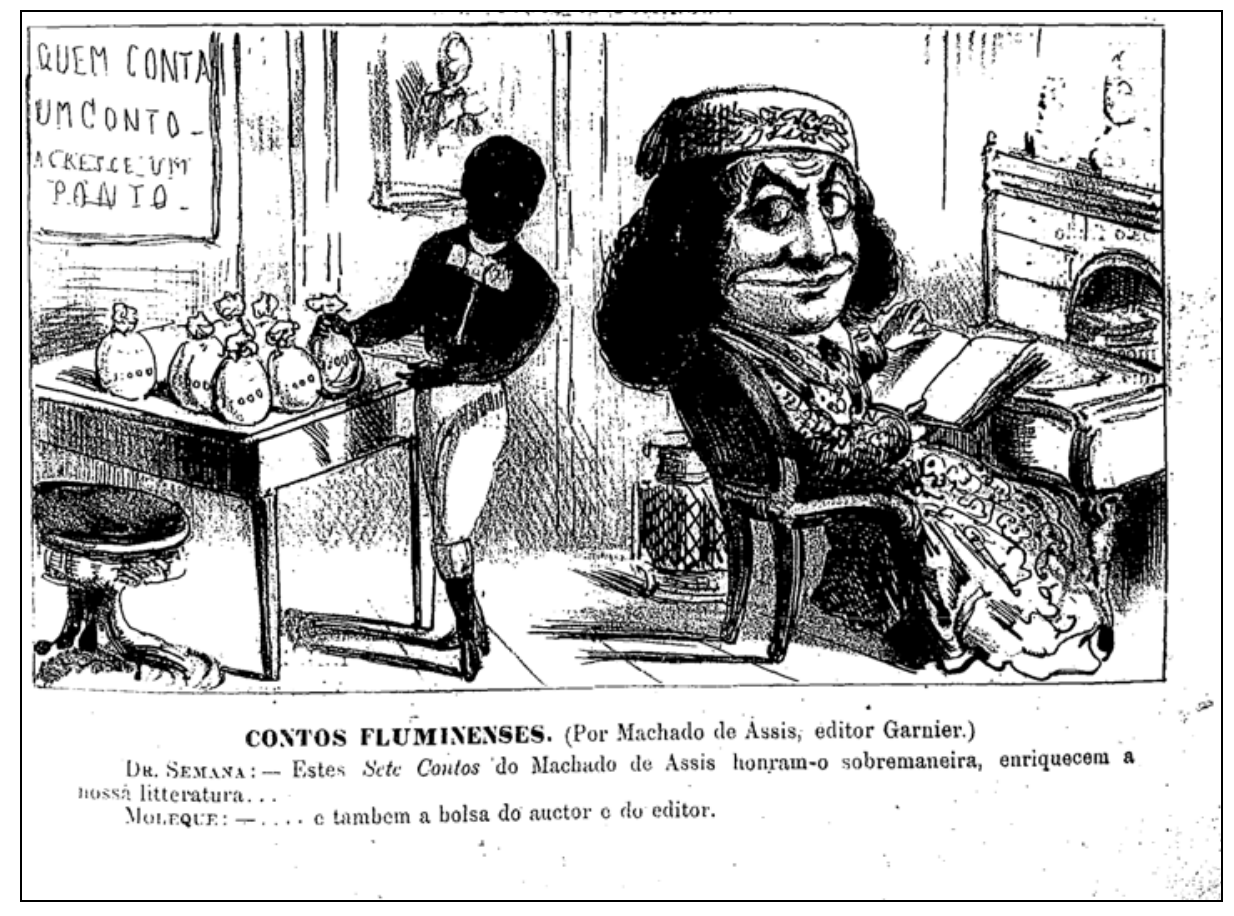

Figura 1: Contos Fluminenses Fonte: Semana Ilustrada, 20. fev. 1870 (Capa)

A coletânea Contos Fluminenses apareceu quase simultaneamente às poesias reunidas sob o título de Falenas (MAGALHÃES JÚNIOR, 2008, p. 140, v. 2). O contrato das Falenas fora 
firmado em maio de 1869, quando Machado de Assis passava por um momento de organização financeira, antecedente ao seu casamento com Carolina. A publicação dessas duas obras visava, dessa maneira, não apenas aprimorar a literatura brasileira, como também envolvia certo retorno financeiro. Contar contos/narrativas significava, conforme se pode observar por meio da caricatura da Semana Illustrada, ganhar contos/dinheiro. Desse modo, o início da carreira de Machado de Assis como escritor de literatura e a publicação sob o formato de livro de uma das suas primeiras obras estiveram intimamente ligados à imprensa periódica de interesse feminino e às demandas dos leitores e das leitoras.

\title{
Notas:
}

\begin{abstract}
${ }^{1}$ Machado de Assis usou as seguintes assinaturas no Jornal das Famílias: “M.A.”, “Max”, “J.”, “Job”, “M.”, “A.”, “F. e S.”, “J.J”, “Máximo”, “Marco Aurélio”, “J.B.”, “Victor de Paula”, “Otto”, “Camillo da Anunciação”, “X.”, “Lara”, "O.O.” e "B.B.".

${ }^{2}$ Numa lista de colaboradores, publicada no ano de 1870, pelo Jornal das Famílias, encontram-se os seguintes nomes: Dr. Augusto Fausto de Souza, Augusto Emílio Zaluar, Bittencourt Sampaio, D. Emília Augusta Gomes Penido, Cônego Francisco Bernardino de Souza, D. Honorata Minelvina Carneiro de Mendonça, Dr. Caetano Alves de Souza Filgueiras, Cônego Dr. J. C. Fernandes Pinheiro, Dr. Joaquim Manuel de Macedo, Joaquim Norberto de Souza e Silva, J. L. Teixeira de Macedo, Dr. José Joaquim Pessanha Povoa, José Rufino Rodrigues Vasconcelos, José Nicolau Vergueiro, Juvenal Galeno, L. G. P. Guimarães Junior, Luiz Antônio Burgain, Machado de Assis, Manoel Inácio Marrocos Mendes, D. Paulina Philadelphia e V. Colonna.

${ }^{3}$ A escolha do "melhor" casamento para os filhos e as filhas deixava de considerar apenas as condições financeiras dos nubentes. A partir de meados do século XIX, embasados por algumas teses médicas, os pais de famílias são levados a considerar o condicionamento físico do casal para gerar filhos saudáveis. Isso produziu dicas, repetidas entre os próprios colaboradores da revista, que indicavam que a união entre pessoas de idades muito díspares, conforme parecia ser comum até aquele momento, geraria filhos com determinados problemas físicos. (NAZZARI, 2001; SILVEIRA, 2010).
\end{abstract}

${ }^{4}$ Antes de "Luís Soares", havia aparecido nas páginas do Jornal das Famílias as seguintes histórias que levavam em seu título o nome ou apelido da personagem feminina: "Diana”, "Francisca”, "Onda” e "O segredo de Augusta”.

${ }^{5}$ Machado de Assis parecia se interessar por situações em que os mortos tentavam permanecer presentes na vida de seus dependentes por meio do testamento. Em Helena, romance escrito em 1876, essa foi a temática que marcou o seus primeiros capítulos. (CHALHOUB, 2003. p. 19-23)

${ }^{6}$ Nos Contos Fluminenses, Machado de Assis nomeou de “Adelaide” três personagens diferentes. Este nome apareceu em "Luís Soares”, “O segredo de Augusta” e "Linha reta e linha curva”.

${ }^{7}$ Entre 1873 e 1876 e também no ano de 1899, foi publicado o periódico O Sexo Feminino - Semanário dedicado aos interesses da mulher. Este possuía como proprietária e redatora a senhora Francisca M. da M. Diniz. Contava com outras mulheres na redação e, em seu primeiro número, defendia a instrução feminina para que, quando as mulheres perdessem seus pais ou maridos, não ficassem desamparadas, afirmando "si meu pai, minha mãe, meu irmão, meu marido morrerem o que será de mim!”. O Sexo Feminino, 7 de setembro de 1873.

${ }^{8}$ Sandra S. M. Koutsoukos atesta que essa prática de se enviar as crianças para serem criadas por amas, geralmente no campo, era muito mais comum na Europa e nos Estados Unidos do que no Brasil (KOUTSOUKOS, 2009, p. 306).

${ }^{9}$ Ver por exemplo "A vaidade corrigida".

${ }^{10}$ Essa mesma questão foi trabalhada, anos mais tarde, por Machado de Assis, quando criou a personagem D. Camila, do conto "Uma senhora”, publicado na coletânea Histórias sem data.

${ }^{11}$ Quem questionou a veracidade dessa polêmica foi Raimundo de Magalhães Júnior (MAGALHÃES JÚNIOR, 2008, p. 372-384, v. 1).

${ }^{12}$ Valeria Augusti analisa essa literatura prescritiva e usada como guia de conduta, partindo do pressuposto de que a aproximação entre ficção e realidade ajudou a garantir o sucesso dessas obras. (AUGUSTI, 2000, p. 90)

${ }^{13}$ Os números divulgados em 1876, do recenseamento realizado em 1872, deixaram a imprensa brasileira bastante preocupada, pois indicavam que apenas $18,6 \%$ da população livre e 15,7\% de toda a população sabiam ler e escrever. 


\section{Referências:}

\section{Fontes:}

ASSIS, M. de. A pedidos. Correio Mercantil. Rio de Janeiro, 02/05/1865.

ASSIS, M. de. Obra Completa. In: COUTINHO, A. (Org.). Rio de Janeiro: Nova Aguilar, v. 2, 1986.

A REDAÇÃO. Jornal das Famílias. Rio de Janeiro, 01/1863.

A REDAÇÃO. Jornal das Famílias. Rio de Janeiro, 02/1869.

A REDAÇÃO. Jornal das Famílias. Rio de Janeiro, 02/1870.

J. A pedidos. Diário do Rio de Janeiro. Rio de Janeiro, 02/04/1865.

J. Jornal das Famílias. Rio de Janeiro, 04/1865.

J. Jornal das Famílias. Rio de Janeiro, 05/1865.

J. Jornal das Famílias. Rio de Janeiro, 06/1865.

O CATURRA. A pedidos. Correio Mercantil. Rio de Janeiro, 01/04/1865.

O CATURRA. A pedidos. Correio Mercantil. Rio de Janeiro, 04/05/1865.

PAULINA PHILADELPHIA. Jornal das Famílias. Rio de Janeiro, 06/1869.

Semana Illustrada. Rio de Janeiro, 20/02/1870.

UM VELHO. A pedidos. Correio Mercantil. Rio de Janeiro, 11/04/1865.

VICTORIA COLONNA. Jornal das Famílias. Rio de Janeiro, 11/1874.

VICTORIA COLONNA. Jornal das Famílias. Rio de Janeiro, 06/1875.

\section{Bibliografia:}

AUGUSTI, V. O caráter pedagógico-moral do romance moderno. Cadernos Cedes, Campinas, ano XX, nº 51, p. 89-102, nov. 2000.

CHALHOUB, S. Machado de Assis, historiador. São Paulo: Companhia das Letras, 2003.

KOUTSOUKOS, S. S. M. Amas mercenárias: o discurso dos doutores em medicina e os retratos de amas - Brasil, segunda metade do século XIX. História, Ciência, Saúde - Manguinhos, Rio de Janeiro, v. 16, n. 2, p. 305-324, abr.-jun. 2009.

MAGALHÃES JÚNIOR, R. de. Vida e obra de Machado de Assis. Rio de Janeiro: Record, 2008. Vols. 1 e 2. 
NAZZARI, M. O desaparecimento do dote: mulheres, família e mudança social em São Paulo, Brasil, 1600-1900. São Paulo: Companhia das Letras, 2001.

PEREIRA, C. M. Jogos e cenas do casamento: construção e elaboração das personagens e do narrador machadiano em Contos Fluminenses e Histórias da meia-noite. 2008. Tese (Doutorado em Teoria Literária) - Instituto de Estudos da Linguagem, Universidade Estadual de Campinas, Campinas, 2008.

PINHEIRO, A. S. Para além da amenidade: o Jornal das Famílias (1863-1878) e sua rede de produção. 2007. Tese (Doutorado em Teoria Literária) - Instituto de Estudos da Linguagem, Universidade Estadual de Campinas, Campinas, 2007.

SILVA, A. C. S. da. Linha reta e linha curva: edição crítica e genética de um conto de Machado de Assis. Campinas, SP: Editora da Unicamp, 2003.

SILVEIRA, D. M. da. As lições de Machado de Assis: literatura e ciência no Jornal das Famílias. Locus: revista de História, Juiz de Fora, v. 30, n. 1, p. 151-166, 2010.

SILVEIRA, D. M. da. Contos de Machado de Assis: leituras e leitores do Jornal das Famílias. 2005. Dissertação (Mestrado em História) - Instituto de Filosofia e Ciências Humanas, Universidade Estadual de Campinas, Campinas, 2005.

Recebido em 24/08/2011

Aprovado em 27/10/2011. 